\title{
Professor Niriellage Chandrasiri - A Tribute
}

\author{
Prof. Ravindra Fernando ${ }^{1 *}$, MBBS, MD, FCCP, FCGP, DMJ(Lond), FRCP(Lond), FRCP(Glasgow), FRCP(Edin), \\ FRCPath(UK),
}

Professor Niriellage Chandrasiri, Senior Professor of Forensic Medicine and Head of the Department of Forensic Medicine, University of Ruhuna, and Consultant Judicial Medical Officer, General Hospital (Teaching), Karapitiya, Galle, was born in Niriella in Ratnapura District on $5^{\text {th }}$ December 1940. Chandrasiri was the youngest son of a well-known Ayurvedic Physician Niriellage Premadasa from Niriella. Subsequently, he was brought up by his mother's sister who lived in Colombo.

Young Chandrasiri received his Primary Education at Royal Primary, Colombo and then joined Thurstan College, Colombo to complete his secondary education. He passed the GCE Advanced Level exam emerging as one of the top 10 students in the country that year.

He obtained MBBS (Ceylon) with Second Class Honours from the Faculty of Medicine, University of Colombo in March 1967 and received his first appointment as Medical Officer at the General Hospital, Badulla.

In June 1968 he completed one year internship as a Pediatric House Officer at the Lady Ridgeway Hospital and as a Surgery House Officer at the General Hospital, Colombo. In 1968, he was appointed as a Medical Officer out Patient Department and Acting Judicial Medical Officer, General Hospital Badulla.

The same year he married Miss Chithra Weerasinghe from Badulla.

${ }^{1}$ Senior Professor of Forensic Medicine and Toxicology,
Faculty of Medicine and Acting Director, Centre for the Study
of Human Rights, Faculty of Law, University of Colombo.
Chairman, National Dangerous Drugs Control Board
*Corresponding author: $\quad \begin{gathered}\text { Prof. Ravindra } \\ \text { Tele:0094718 }\end{gathered} 571 \quad$ 953, e-mail rnando,
address: ravindrafernando@hotmail.co.uk
After serving seven months from January 1969 as a House Officer at the District Hospital, Haputale, he joined as a Lecturer in Forensic Medicine, Faculty of Medicine, University of Ceylon, Peradeniya on $1^{\text {st }}$ March 1970.

In 1972, he went to the UK for his Post Graduate studies as a Colombo Plan Scholar. He followed his training, under Professors Gilbert Forbes, Professor of Forensic Medicine, University of Glasgow, David Bowen, Charing Cross Hospital, London and J. Malcolm Cameron, London Hospital Medical School.

He was successful in the MRCP (UK) examination in 1973. He also obtained the Diplomas in Medical Jurisprudence in both Clinical and Pathology Divisions. In 1985, he was awarded Doctorate of Medicine by the Post Graduate Institute of Medicine, University of Colombo.

On his return from the UK, he was promoted to Senior Lecturer grade in Forensic Medicine of the University of Ceylon, Peradeniya.

He accepted the appointment as the first Professor of Forensic Medicine of newly established Faculty of Medicine of the University of Ruhuna on $21^{\text {st }}$ April 1981.

Apart from lecturing medical undergraduates, he was responsible for medico-legal work in the Galle District and was the Medico-legal Consultant to police in the entire Southern Province. In fact Prof Niriella was the only medico-legal specialist in Southern Sri Lanka until 1999.

In 1989, the year of murder and violence in the country, especially in the South, when none of the academics was willing to take up responsibility of functioning as the Dean of the Faculty of Medicine of Ruhuna University, he volunteered to do so. Three months later he was elected the Vice Chancellor, the highest position in the University on $1^{\text {st }}$ October 1989. He served in this position for two terms till January 1995. In August 1990 and August 1993, he attended the Conference of Executive Heads of 
Commonwealth Universities held in New Delhi, India, and Swansea, Wales, respectively.

Considering his achievements and contributions to the medical professions he received the Fellowship of the Royal College of Physicians and Surgeons of Glasgow, Glasgow, United Kingdom and the Fellowship of the Ceylon College of Physicians in 1992.

On $15^{\text {th }}$ May 1977 he followed a 3-month course in Insecticide Poisoning at the Institute of Occupational and Radiologic Health, Belgrade, Yugoslavia.

Professor Chandrasiri was a member of many professional bodies. In 1980, he became a member of the Medico-Legal Society of Sri Lanka and a founder member of the College of Pathologists of Sri Lanka in 2000. In 1987, he became a member of the Sri Lanka Association for Advancement of Science or SLAAS and the Sri Lanka Medical Association.

As a professional interested in child protection activities, he served as a member of the National Committee on Rehabilitation of Unprotected Children in 1996 and a member of the Ad hoc Committee to Formulate a New Medico-legal Report to be used in the examination of cases of child abuse in 1998.

In 2002 he was elected President of the College of Forensic Pathologists of Sri Lanka, the apex professional body of the Forensic Pathologists in this country.

As a Board Certified Consultant in Forensic Medicine and Honorary Specialist Judicial Medical Officer, General Hospital (Teaching), Galle, he was elected Chairman, Board of Studies in Forensic Medicine and Coordinator, Academic Programmes for Diploma in Legal Medicine and Doctorate in Forensic Medicine conducted by the Postgraduate Institute of Medicine, Colombo. During his tenure, he trained many post-graduates and was the supervisor for postgraduates studying for Diploma in Medical Jurisprudence and Doctorate of Medicine in Forensic Medicine.

He was an examiner in Forensic Medicine, Postgraduate Institute of Medicine, Colombo, and Universities of Colombo, Jaffna and Peradeniya. It was a pleasure working with him as a co-examiner.

He was a member of the consultative committee of the Human Rights Commission of Sri Lanka.
As an internationally recognized expert in the field of Forensic Pathology, Professor Chandrasiri was selected as a Consultant Forensic Pathologist in the team along with pathologists from Scotland, England, United States, Guatemala, Chile, Iceland, Turkey, Denmark, Ethiopia, Argentina and Netherlands in the investigation of mass graves in Bosnia, former Yugoslavia in July 1996, where he conducted autopsies. He documented his work in an article titled "Experiences of a forensic pathologist in the examination of a mass grave in former Yugoslavia” in the Ceylon Medical Journal in. 1997.

He was also a member of the International team of Forensic Pathologists, Forensic Anthropologists and Forensic Archeologists which conducted excavations and identification of civilians and soldiers who were buried in the cemeteries of Nicosia and St Helena, Cyprus after the invasion of Cyprus by a Turkey in 1974.

He worked as a Consultant Forensic Pathologist from March 1 to May 31, 2000 under the United Nations Transitional Administration in East Timor in conducting Forensic exhumations and autopsy examinations of cases of human right violations, which occurred from January to September 1999 in East Timor. Based on his experience he read a paper titled "Medico-legal aspects of genocide in East Timor" at the $6^{\text {th }}$ International Medical Congress, organized by the Peradeniya Medical School Alumni Association and the Faculty of Medicine, Peradeniya

In 1983 he spent his one year Sabbatical leave performing research on cardiac conduction tissues, in the Department of Forensic Medicine, University of Leeds, UK, under the guidance of Professor David Gee. His work was published in the prestigious British journal, "Medicine, Science and the Law" in 1985 titled "Restudy of Histopathological Lesions of Human Cardiac Conducting Tissue in 785 Coroners Autopsies" and in 1987 in the "Ceylon Medical Journal' titled "A simple method of studying cardiac conducting tissues".

In 1986 he spent his one month Fellowship to study day to day work on coroners' autopsies in the Department of Forensic Pathology, National University of Singapore with Professor Chao Tzee Cheng.

In August 1988 he was awarded a 3-week World Health Organization Fellowship to study the 
Medical Examiner System in USA and he conducted autopsies on Gun Shot wounds in Coroner's Office, Los Angeles, California.

In May 1999, he followed a training programme sponsored by the WHO for one month under Dr. William Goodwin of the Department of Forensic Medicine, University of Glasgow in theory and practice of DNA extraction, gel electrophoresis, PCR amplification, gene sequencing etc.

Paraquat was a highly toxic non-selective herbicide, which was widely used in Sri Lanka. It was used for suicidal purposes with some 300 to 400 deaths annually. Professor Chandrasiri in 1999 reported the first ever case of homicidal poisoning by intramuscular injection of paraquat in the 'Ceylon Medical Journal'. Import of paraquat to Sri Lanka was banned in 2010.

When a dead body is found in a river or sea, a common medico-legal problem is to determine whether the death was an accident, suicide or murder, as it is sometimes difficult to determine whether the person was killed and the body was dumped into a river or sea. Professor Chandrasiri published an article on "Detection of diatoms in the marrow of thigh bones as evidence of death by drowning" in the 'Ceylon Medical Journal' in 2001, highlighting differential diagnostic aspects of suicidal drowning and post mortem immersion.

Professor Chandrasiri's expertise had been rendered in several important medico-legal investigations in Sri Lanka. A prime example was when the popular monk Reverend Gangodawila Soma died in December 2003 while visiting Russia. Some of his followers argued that his death was part of a larger 'conspiracy against Buddhist revivalism.' However, the post mortem conducted by a team of forensic medicine experts headed by Professor Chandrasiri Niriella determined that the death had occurred from entirely natural causes. The panel had determined that the immediate cause of the death was "Myocardial Infarction", a heart attack, of the apical region of the left ventricle, subsequent to the blockage by a thrombus (blood clot) in the left descending coronary artery and severe arteriosclerosis and calcification of the artery. The report showed that Reverend Soma had an old fibrotic area in the left ventricular wall, indicating that he had a previous heart attack.

Chemmani is a largely uninhabited flat paddy land lying along the Kandy-Jaffna A9 trunk road to the east of Ariyalai village. The Chemmani checkpoint is located at the municipal boarder of Jaffna town and about 50 miles towards Jaffna from a concrete arch across the Kandy-Jaffna A9 trunk Road.

Somaratne Rajapakse, the first accused in the Krishanthi Kumaraswamy rape and murder trial revealed about Chemmani graves in High Court of Colombo on $3^{\text {rd }}$ July 1998. According to Rajapakse's revelations there were several mass graves containing about 300 bodies in Chemmani and in surrounding areas in Jaffna Peninsula. These were the bodies of Tamil civilians who were arrested on suspicion for terrorist involvement, tortured and killed by the security forces following Riviresa operation in April 1996. When questioned by the officers of the Criminal Investigations Department (CID), the other convicted prisoners of the Krishanthi Kumaraswamy trial confirmed what Rajapakse said and informed CID that they are willing to show the graves only to the Magistrate at the commencement of excavation.

On $8^{\text {th }}$ January 1999 the Criminal Investigation Division of the Sri Lankan Police made an application in the Jaffna courts:

1. To obtain an order for exhumation of the alleged human remains at Chemmani.

2. To order the commissioner of prisons to produce suspect ex-Lance Corporal Rajapakse to identify the alleged place of burial at Chemmani.

3. To order Professor Chandrasiri Niriella (forensic expert) and Mr. M.A.J Mendis, additional government analyst, to assist the exhumation work.

The Medico-legal investigation of alleged mass graves in Chemmani was a unique event, because it was the first occasion where such a complex investigation was undertaken in Jaffna peninsula of Sri Lanka where there was an ongoing civil war. This decision has been hailed as a courageous step by the United States government and has commended Sri Lankan government for investigating 
the human rights violations committed by its own security forces.

The objectives of the Chemmani investigation were to identification of the graves, exhumation of the bodies, ascertainment of the cause and manner of death, establishment of identity of the dead and institution of criminal proceedings against those responsible.

As the Magistrate stated that any interested party could bring forensic experts for this investigation, Dr. W. D. Haglund, Forensic Anthropologist and Director of International Forensic Medicine Programme of Physicians for Human Rights (PHR) in United States of America, Ms. Melissa M. Conners, Forensic Archaeologist of PHR, Mr. R. D. Stair from the Coroner's Forensic Identification Unit of Ministry of Attorney General of British Colombia, Canada. Drs. Kevin P. Lee Forensic Pathologist from Australia and Ms. Tal Simmons, Forensic Anthropologist from USA participated as foreign observers.

Mr. Yasantha Kodagoda, the present Additional Solicitor General of the Attorney General's Department, a geological expert Professor Nandasena of the University of Peradeniya, Government Analyst Mr. Ananda Mendis, Director of CID Nandana Munasinghe and Jaffna Police OIC Ratnayake were present in Jaffna for the investigation.

Professor Chandrasiri was the Chief Medico-Legal consultant to the expert scientific team that investigated the alleged mass graves at Chemmani, Jaffna, Sri Lanka, from March to September, 1999.

Based on his experience he published an article titled "Adaptation of archaeological techniques in forensic mass grave exhumation: the experience of Chemmani excavation in northern Sri Lanka" with Dr. Clifford Perera, Dr. P. R. Ruwanpura and Dr. H. T. Wijeweera, all his students, in the Ceylon Medical Journal in 2006.

Professor Niriella has published three books. The first, a book titled "Medical Evidence and the Role Judicial Medical Officer (Forensic Pathologist) in Culpable Homicide" was published in, 1988.
In 1997, outlining the value of trace evidence he published a collection of 16 short stories titled Nihanda Sakshi or Silent Witness. This 203page book, written in Sinhalese illustrated the applications of forensic medicine in the solution of assorted medico-legal problems including crimes.

Professor Chandrasiri also published a book titled "Textbook of Clinical Forensic Medicine and Forensic Pathology" in 1999, containing 56 chapters in Clinical Forensic Medicine and Forensic Pathology for the tropics.

Professor Chandrasiri was a popular lecturer in many meetings and conferences.

In 1998, he was invited as a Guest Lecturer for a Seminar for Judges organized by the Sri Lanka Judges' Institute to speak on "Frontiers and modern trends in Forensic Medicine".

In 2004, rolling wave's 90-feet high were triggered by a 9.0 magnitude earthquake off the coast of Sumatra. Waves swept in killing more than 230,000 people across 14 countries. It was one of the deadliest disasters in recorded history, at its most devastating in Indonesia, followed by Sri Lanka. The Tsunami disaster in Sri Lanka took over 30,000 lives, and thousands were displaced. Thousands of dead bodies were buried in mass graves without any identification as the medico-legal services could not cope up with numbers.

Professor Chandrasiri led a team to exhume the bodies of 24 Britons in a mass grave at Kirinda in Hambantota for DNA testing and identification. He also led the team that exhumed four mass graves at Kirinda. He said teeth and samples of muscle and bone tissue would be obtained from each body for DNA testing. Professor Chandrasiri and a team also exhumed 15 bodies of Germans in Unawatuna after obtaining an order from Galle Magistrate.

In 2005, former President Chandrika Kumaratunga conferred him with the 'Vidyanidi' award - one of the highest national honors - for his post-tsunami work.

He retired after 30 years service in 2005 . 
When Professor Chandrasiri was ill, I visited him at his residence in Karapitiya in early 2006. Sitting on his bed we spent about an hour discussing many things. He was always a friend whom you could trust and discuss any controversial forensic issue.
He passed away at his residence on $8^{\text {th }}$ March 2006 at the age of 65 . Professor Niriella left his wife and three children, who are also academically successful. Two of his sons are medical specialists and the other is a qualified architect.

May Professor Niriellage Chandrasiri attain Nibbana. 